pally based on the subjective symptoms, and I believe that that is thoroughly correct, beciuse so far as concerns the objective symptoms, the palpation of the thrombosed pelvic veins, I ngree with Dr. Vineberg that it is very diflicult; it is only in exceptional instances that we can palpate those veins. The best way is by rectovagiual palpation and even by that method the dingnosis is not ensy. I believe that the condition of the blood is not a good guide at all. The mere pres. ence of microorganisms in the blood is not a criterion as to the prognosis. Mieroorganisms may be cireulating in the blood of a patient who recovers without trentment. I lave seen a number of such instances and have watehed them earefully Again, there may be other instances in which we may not be able to establish the presence of mieroorganisms in the blow and those patients will die, undoultedly of a septic infertion. 1 believe that while the examinution of the bloot is important in establishing the presence or the absence of a bacteriemia. it does not give us an exact prognosis. I believe that when we lave such instanes ne Dr. Vintoberg has reported, multiple abscess in the uterus complicating the condition of thromlwphlebitis, there is only one course, that mentioned by lim, extirpating the nterue at the aume time. (On the whole, believe that in this subject we are still in donbt. We cannot come to a definite conclusion until we have made further research, until we have gnined further information from the laborntory. On the mutter of vaecines $1 \mathrm{~nm}$ at a loss to give an explanation. We have instances in which we huve trented our septic patients with vaceines and some recover. $13 y$ en tinuing with the work which lus been laid out for ns, with the surgieal intervention wherever we enn nake our clingnosis, and give heed to what the laborntory may tell us in regard to vaccines, in the course of time we may be able to give a more deflnite opinion as to our trentment in this condition.

D). C. O. Tumenusus, Milwalkee, Wis.: Agreeing fully with the views taken by Dr. lluggins 1 would like to ald to the literature of the subject reports of two cases which hatp. pened in my own practice. In the first ease, which I saw eight day's after confinement, the womm had had four chills on the sixth day und five chills on the seventh day. Being certain that the physicinn who called me into consultation could not have overlooked remnants of placenta left within the nterus I nivised immedinte laparotomy. I found thrombophlebitis present, and not only ligated the veins but removed tho uterus in the wall of which 1 found numerous sminll absecsses. The woman recovered. I believe that in such acute cases as this the best procedure is not only to lignte the veins, but to remove at the same time the locus prima formations of infection, that is, the uterus. The second pationt loperated on six weeks ufter conflnement, the womm sullering from ehills irregularly every wecond or third day since the fifth day following confinement. Juring examinution I found the uterus freely movable, the right ovary slightly enlurged nud very painful to touch, but also freely movable. On opening the ablomen $\mathrm{T}$ fouml thrombophlebitis and a ovarium on the right side. I ligated the veins and removed the right ovary. 'The chills, however, continued and the patient died fourteen ditys after the operation. It is interesting to know that a pyovariun muy be freely movable.

Dr. 'T. J. Wa'tzins, Chicago: A feature of this subject that has not been considerel is the question of the estimate of results. The operation for phlebitis as done by the aurist is alway' done in comnection with the mastoid operation. Consequently, it is extremely dillicult to estimate how much value is oblained from the mastod operation and low much value is oltained from the ligation of the veins. In thrombo. phlebitis aflecting the leg, one never thinks of operating. What is acoomplished by ligating the vein in thrombophlebitis? Does the ligature prevent the extention of the bacteria or of the toxins, or limit the extent of the blood-clot? It wond seem not to accomplish any of these results. Tho injury to the intima of the vein and the strangulation of some tisane in the ligatures would seem to do moro harm than goot. Those who are advocnting ligntion for thrombophlebitis should give us some accurate information as to what the operation accomplishes.
1)R. R. R. Huarans, Pittsburgh: I have tried to emphasize tho importance of the clinical symptoms in the diagnosis of thromboplilebitis: the presence of high tempernture, falling in n few hours to normal or below; the recurrence of ehills, not necessarily present. however; the falling of the pulse with the lowered tempernture; the improvement in the general appenrance of the patient with the change of the above symptoms. In septicemin the pulse runs much higher than the tempera. ture and there is not the disposition to periods of improvement. 'lliere are but two points to consider in the discussion; the first is dingnosis and the seeond indication for operation. There is no doubt that many patients with mild attacks reover and certainly many of those with severe attacks dir. The first case to which I have called attention is that of a woman almitted to the hospital after an eight days' illuess, with a temperature ranging between an and 104.5, with frequent recurrence of ehills; she was studied enrefuly. Blood. cultures were negative; there was no evidence indienting a loctlized infection in the pelvis. Clinienlly it was not a case of septicemia; there was slight tenderness at the outer margin of the right brond ligament, extending upward along the inner side of the nuterior superior spine. In view of the doubt, an exploratory laparotomy was done which revealed a throm. hosis of the right ovarian vein. Becanse it was fenred that there might be some infection outside of the vein, the midline incision was closed and an extraperitoneal incision made. The serond case is one in which cesarean section was done for a ruptured uterus. The temperature remuined up for several days following the operation, blood-cultures were negative, und there were no puin or other local symptoms. After the second chill, operation was done and thrombosis of the right ovarian vein was found. If Dr. Watkins had been present at the operation and witnessed the pus and filth within the vein, he could understand why placing a ligature above the point of infection was a rational procedure.

\section{TUBERCULOUS MENINGITIS}

\section{a PATHOLOGIC REPORT OF NINE CASES *}

\section{JOHN H. W. RHEIN, M.D.}

l'rofissor of Diseases of the Mind und Nervous System at the Philadelphin Iolyeltule and College for Graduntes in Medieine Nourologlst to the Iloward Hospltal; Vlsiting Physlclan to the Iblladelphin liome for Incurnbles 1'III,A DH:HPIHA

I recently had the opportunity of examining histologically nime cases of meningitis, seven (Cases $1,2,3,4$, 5,6 and 7 ) of which had been diagnosed clinically and pathologically as tuberculous meningitis. Case 8 had been dingnosed as one of tubereulous meningitis from which the patient recovered only to suecumb a month later to an attack of pnemmonin.

The findings are interesting as showing the histologic features in a recovered case of meningitis.

Case 9 was dingnosed clinically and pathologically as pnemmococeus meningitis and is of interest in comparison with the findings in the tuberculous enses.

As far as possible the material was taken from those regions of the cortex where the tubercles were not found. While all the sections were stained for the tuberele bacillus, none was discovered in uny case alter careful senrels. Tt should be mentioned that some of the specimens were harlened in Kaiserling, which may have alfected its staining properties for the tuberele bacillus. 'The results were interesting and instructive and, though they do not permit the drawing of any positive conclusions, they suggested some ideas which are worthy of mention.

- From tha IIowald Hospltal, the Chlloren's lospltal and the Department of Neurology and the Laboratory of Neuropathology of the Ualversity of I'ennsylvaula. 
It seemed possible that the lesion which was fairly uniform in its histologic character was caused not ulone by the tubercle bacillus, for reasons which will bo developed later on in this paper. It further seemed possible that the meningitis was due to a mixed infection. If this could be proved it would seem lout a step further to obtain a vaccine which might operate against suchl a process. If this could be successfully combated, there then would remain the tuberculous process alone, which in itself may be looked on as less fatal than the mixed infection, and within the possibility of eure.

Experiments are now on foot, in conjunction with J). Terbert Fox, with this end in view and a report will be mate later, embodying the results of these experimentations.

I am indebted to Dr. J. Crozer Griffith, Dr. J. C. Gittings and Dr. Alfred Hand, for the privilege of reporting somc of these cases, and Dr. C. Y. White for the pathologic material from these cases from the Children's Hospital.

Cass 1.-Patient.-A. P., aged 12, was admitted to the Children's JInspital Sept. 14, 1905. The family and personal histories were negative. The symptoms dated from the day before admission and consisted of fever, delirium, persistent vomiting, lendache, drowsiness and slight stiffness of the neck. On admission the aldomen was distended und there was olstinate comstipation. Examination of the lungs was negative and also of the heart except that it was rapid. 'Jhe pupils were dilated and equal. Kernig's sign was present. 'The hend was retracted and tache céribrale was demonstrated. Numerous dark-brown spots seattered over the body were seen. Jater the legs beenme rigid, the face was drawn to the right, and denfness ensued. Jianmination of the eyes, by 1)r. William Camplell Poscy, was negative, except that the pupils were dilated.

An irregular temperature marked the course of the disease ranging from subnormal to $1043 / 5$. The patient was most of the time in a semintuporous state, and died November 20.

dutopsy.-The dura was opaque and thiekened. The piaarachnoid was also opaque and thickened, and areas of exudate were olserved on the base, the convexity and along the sylvian fissure. A few miliary tubercles were observed. No tubereulous process was scen elsewhere.

Microscopic Study.-The pin was the seat of a romel eell infiltration, the cells heing mainly of connective-tissue type, though there were somo mononuclear round cells. Comnectivetissue formation enclosing hlood-pigment and numerous bloodecills was also observed. The comnective-tissue colls showed in places vacuolization and some contained blood-pignent. The intimn of the arteries and veins was thickened and whowed proliforation of the comnective-tissue cells. The pir of the modulla was the seat of a marked round cell infiltation, the colls consisting of sinall mononuclear cells and large polynuclear cells. In the eortex there was a marked degree of porivascular dilatation but the cortical cells stainet well.

This case was of the mixed type, the proliferative type predominating in the pia of the cerebral rortex, and the exudative type in the pia of the medulla. This case was clinically one of tuberculous meningitis and while no tuberde bacillus was found in this or, indeed, in any of the cases of this series, microscopically it coinr.ifled with the usual histologic characteristies of this disease.

Case 2.-Pationt.-M. H., aged 13 months, was admitted to the Children's Jlospital Mareh 16, 1906. Jistories, fumily nud persomal, were negative. The patient died Mareh 25, seven weeks after the onset of the disease, thongh the nervous symp. toms preceded death lut three weeks. The first symptom eonsisted of diarrhea with green stools. A month later the child was seized with convulsions affecting the left side of the face, arm and leg. 'l'he eyes were turned toward the right and later the right side of the face, the right land and foot were convulsed. The movements vere more or less continuous and there wus some genernl rigidity which later became very marked, the legs and arms being held in extension. Kernig's sign was not elenrly demonstruted. The knee-jerks were not inerensed. Jumbar puncture was done without effect on the symptoms. 'The heart was rapid and there was some dyspnen. There wero no spots on the boly and examination in other respects was negative. The temperature runged from 09.2 to 104.4 .

A utopsy.-There was found general tuberculosis involving the lungs, epicardium, peritoneum, kiduey's, stomach, intestines and lymph-glands.

Mieroscopic Hamination.-The infiltration of the pia consisted mainly of cells of the conncetive-tissue type. Mnny plasma cells, however, were present. Numerous red blood-cellis wore found in the thickened pin. The veins were slightly thiekened, the intima showing a marked proliferation of the comnective-tissue cells. There was a slight perivascular distontion and slight perivaseular infiltration of the cortex.

In this case in which the nervous symptoms manifested themselves for three weeks only before death, there is evidence clinically of an acute process. 'The type of cellular infiltation is strikingly proliferative. The presence of blool in the process is worthy of mention as being present in both the exulative and proliferative forms of tuberculous meningitis.

Case 3.-Pationt.-R. S., uged $61 / 2$ yeare, was admitted Nov. 14, 1006, to the (hildren's llospital and died November 28. The fumily and personal histories were negative. Duration of the disease was twenty-two days and began with loss of appetite, headache, slight enlargement of the tonsils and fever. On admission the examination of the lungy and heart, abdomen and splecen was negative. 'Jhere was marked tache cérébrale. The patient was irritalsle and lay enrled up on one side. There developed then rigidity of the neck, dysphagin and genernl convulsions. Kernig's sign was present on the sixth day. 'The putellar reflexen were irregular, being sluggish on the right. Paralysis of the left external rectus was present associnted with nystagmus. Bubinski phonomemon was present and finally Cheyne-Stokes respiration.

Aulopsy.-A diagnosis of tubereulous meningitis was made, though no note of any tubercles was made at the time of the neеropsy.

Microscopic Examination.-The pia showed the presence of a dense infiltration which contained many mononuelear and polymacenr lenkecytes. In other places the cellular infiltration consisted largely of endothelial cells which was very marked around the blood-vessels. Red blood-eells were numerous and a number of plusma cells were observed. Where the tissue was loose the cellular infiltation was composed largely of lymphocytes and lenkoeytes, but where the tissue was denser the connective-tinsue cells predominated. The blood-vessels showed some thickening of the walls, and in places aceumulation of round cells benenth the intima was pronounced.

In the eortex there was perivasenlar distention and slight round cell infiltnotion around tlie blood-vessels. Murked encephalitis was observed, the lenkoeytes predominating in the exudute.

This case illustrates the mixed form, showing the presence of both the exulntive and proliferative type of tubereulous meningitis.

(Asi: 4.-Paticnl.-M. E., aged 19 months, was admitted to the Children's Hospital $A$ pril 24,19015 , and died two days after admission. Her mother had died of tubereulosis, four months previonsly, but otherwise the famuy history was negative. The patient had suffered from a cough and general irritability for four monthe previously.

'l'wo days before almission she became first dull, then unconscious. She was able to move the left side of the fuce only and the eyes twitehed at times. There was genernl rigidity, more on the right side. 'The left eyeball was drawn inward and there was also palsy of the right external rectus. Kernigg's sign was not defluite.

In the lungs conrse moist and fine dry rnles were audible. The splcen was palpable and the liver enlarged. Examination 
of the henrt was negative. The temperature ranged from $n 8$ to 102.8 .

Autopsy.-A diagnosis of general tubereulosis was made involving the lungs, liver, splesen, lidneys, intestines and meninges. The exudate over the meninges oceupied the posterior and superior surface of the cortex posterior to the millle line. The base of the brain was also the seat of inliltration.

Mierosoopic finamination.-In the pin the infiltrution was made up of leukocytes and lymphocytes minly. In places there was present in the pin large quantities of red blood-eells. The process was manly of an cexblative type. The cortex was invaled in places, the eells in the subeortical layers heing of the monomuclear type and entuining darkly-staining nuckei. but polynuclenr cells and some plasma cells were also observed Perivascular distention of the cortex and round exll intiltration around the vessels were present. Obliterntion of the small vessels with some slight proliferation of the intima in others was noted.

This is an example of the purely exudate type of meningitis. The cace was a rapid one, the evidence of meningeal implication lasting but four days.

CAsE 5.-Patienl.-II. P., aged 2 years, was almitted to the? ('hildren's Ilospital Mareh 25, 1906 , and died Mareh 31. The? fumily and previous histories were negative except that one sister diol in spmsms. There was no history of tubereulosis. The ehild lind boen siek for two weeks bofore admission. making the duration of the disease cighty-one days. The dis ense was ushered in with vomitang, constipntion, slight congh and somnolence.

On anmission the ehild was unconscious, the eyes were open, the pupils large, roncting sluggishly, strabismus was present and there was rigidity of the neck and extremities. The kneejerks could not be developed, though ankle-elonus mod tome Jubinsli phenomenon were present. Kernig's sign was posi tive. The temperature ranged from 98 to 100 until just before death when jt rose to lob.2.

Autopsy. $-A$ dingmosis of tuberenlons meningitis was made and miliary tulereulesis of the lumge, liver, liduegs, spleou, intestines and broncluial ghands was present. Jhere was nu exuchte over the motor region on the right side and also nt the buse.

Microscopic stuly.-']he pin was thekened, this being duo to fibrous tissue contuining muny commective-tissue cells and a few round cells. Fome red blool-endls were found in the thickened jin. She veins wore surrounded by many connedive-tissue muelei, but the blood-vessels themselves were not impliented.

'The cortex was invaded by the process. There was some perivascular dilation and the blood-vesiols were distended and showed slight proliferation of the intimu.

'l'he proliferation type of tuberenlous meningitis pledominated in this ase. The process was not extensive or very intense, and was evidently, as the clinicul story would indicate, a chronic prouss.

Case 6.-l'aticht.-13. P., aged $31 \frac{1}{2}$ years. was ndmitted to the Howarl Hospital fou. 12, 1908, and did Janumy I3. 'The family and previous histories were not obtnimable. Pationt on nolmission showed paralysis of the right side of iln! face, right nrm and legr. The right arm was flexed nnd was distinctly spastic. 'The loft arm and leg was kept in constant motion. Movements of the head were painful and disclosed stilfness of the neck museles. The right biceps-jerk was increased but the loft eould not be olicitel. Both knee-jorks were incrensed nul epually so. Babinski phenomenon was present on both sides lut nukle-celonus was ulsent. The pupils reacted normally. Jemperature ranged from 102 to 105.

Aucopsy.-This revealod the presence of tubereulous meningitis and hycrocephalus. Milingy tubereulosis of the kidney and peritonemu was observed.

Aficroscopic stwiy.-The pia from the paraentra! region was the sout of $n$ donse prosess which impliented both the pia fud the superficinl corticul lingers. Commective-tissue cells prodominated, though there were some trifoil cells but these were mainly perivaseular and were present where the inflitrative lesion was less dense. 'The connective-tissue cells were found in various stutes of degeneration many of them showing vaeu. olization. In the superficial layers of the disensed pin the loose connective tissue was infiltrated with mononuclear and polynuclear colls, and a few plasma cells, and was also the seat of extensive extravasntion of blood.

In the frontal region the same condition obtained. In this regrion the blood-vessels were disensed, the outer walls being the seat of cellular acenmulations. The eortex had been invaded slightly in places, the tissue being loose and the sent of some space formation. Just below the pia there was present cellular infiltrution, some colls being mononuclenr romol cells, some being pale and gramular without n demonstrable mueleus, some clongated cells, some cells with two nuclei, some trifoil cells and some large cells with many nuelear frugments tending to unlergo vacuolization. Phagocytosis was also observed in the subcortical hy yers.

'She cortex of the cerebellum was the sent of a marked encephalitis. The pia of the cord was the sent of a mono. muelear round cell inliltration of moderate intensity and the posterior roots wore infiltrated with cells of similar mature. "Whe anterior roots wre simnlarly affected, but to a less degree.

'This case belonged to the proliferative type of tuber(1ulons meningitis, but. the characteristics of the exulate 1 1) of the disease was also present to a marked extent, and it therelore more properly comes under the head of the mixed type.

('As: $7 .-$ l'atient.-V. S., aged 2 years, was admitted to the llowaret Hospital Nov. 4, 1907, and died November 8. 'The family and previous histories were unobtainuble. The child was admitted with tumor of the abdomen which proved to be a distended hludder.

Framination.-The patient was semicomatose on admission. The pupils did not renct to light and the eyconlls yere moved from side to side constantly there being a tendency to left comjugate devintion, with trinsient wonkness of the left internal retus. The sealp and the nape of the neck were tender to pressure and the head was retracted. There was general rigidity of the limbs and from time to time a clonic spasm of both arnis. Tache corebrale was present. The knee-jerks could not be elicited, probably due to the rigidity, and the l3abinski phonomenon was observed on both sides. The exnmination of the eye-gromuls, by 1)r. William Campbell Posey, was negativi.

Autopsy-Ceneral tuberculosis was found of the lungs, liver, mesentrie grands and nlso the meninges, though microscopienlly no tubercles conld be observed in the process in the meninges.

Microscopic Study.-The pia was much thickened and contained leukocytes and connective-tissue colls. The cells were minly of the connective-tissue type, though nany plasma cells were present and some red blooi-corpuseles. The blood-vessels showed marked cellular proliferntion of the walls. Around the bloot-ressols there was marked cellular accumulation of connective-tissue cells. The cortex was the sent of encephalitis in places and there was perivaseular distention, the cortex being in places rarifled.

'l'his case belongs to the proliferative type of tuberculous meningitis.

(Ask 8.-Patient.-J. R., aged 6, was admitted to the Children's Ilospital Jan. 27, 1906, and died January 30 . The family nul provions historiey were entirely negative. She had previously been trented at the Children's Hospital for an atluck of meningitis, which lasted from leec. 1, lnoji, to December es, whon she was disehnrged as cured, save for paralysis of the externul rectus muscle of the left eye.

At that time she had sulfered with rigidity of the cervieal muscles and of the legr which were held in extension. Kernig's sign was present and there was paralysis of the external rectus of the left eye, which remained paralysed. The kneejerks were absent and there was no ankle-clonus or l3abinski phenounenon present. The pulse was irregular and intermittent. The tomperature was not characteristic and ranged from 97 to 104. Fixamination of the fluid obtained by lumbur punc ture showed the presence of intercellular diplococeus and an cxcess of polymorphonuclear cells. A month after her dis- 
charge the returned with symptoms of lobar pneumonia from which she died in a few days.

Autopsy.-The pathologic dingnosis was double lobar pneumonia und acute fibrinous pleurisy. 'Tle lung showed some cavity formation and pulmonary tubereulosis was probably present, including some miliary tubereles. Ardehmoid was congested except over the frontal lobes.

Microscopic fixaminetion.--The infiltration in the pia was not intensoly cellular. There were some leukocytes in small quuntities, numerous round colls, numerous eonnective-tissute eelis and some large round mononuclear cells. Many red bloodcolls were seens. Some of the conncetive-tirsue cells showed advaneed vacuolization and some contained blood-pigment. Other cells stained deply and contained dark round muclei. The vessels of the cortex were filled with red bloot-eells, the walls were thickened, showing hy'dine degeneration and some of the vessels were obliterated. 'llore was perivasenlar romm. cell infiltration of the contex which was rarified, Fresh hemorrhages were found in the subcortienl layers which was also the seat of a slight cellular infiltration.

In this case a diagnosis of tubereulous meningitis hat been made, from which the patient male a recovery, having been discharged as curel. It muy have been, and probubly was, a diplococeus meningitis, though the presence of cavity formation in the lmugs leaves some doubt as to whether or not it was not actually a case of tuberculous meningitis after all. 'This case is interesting as illustrating the alleged cures of tuberculous meningitis, about the exact nature of which, however, it seems to nie there is seme doubt.

'The microscopic findings were similar to those found in tubereulous meningitis of a proliferative type but less marked. Adrled to this there was evidene of an old process in the fibrous mature of the prosess and in the presence of clegencrated cells.

The cortical lesion was of two kinds, an old process, represented by the rarification of the cortex and degenerated blood-vessels, and a recent process chanacterized by fresh hemorrhages and some round eell infiltration, perivascular in type.

'J'he older process, I take it, was the remains of the diseased condition from which the child recovered, apparently, a montl prior to the onset of the fatal pneamonia. 'The nore recent process could be explained by a meningeal extension of the pmeumocosens invasion.

Case 0.-l'utient.-J. S., ngod ] yonr, almitterl to the Children's Ilompital September 26, lout, died Oetober 21 . The family and jrevious histories were entirely negative. The chikd was breast-fed from birth. The duration of illness was thirty days and loogne with high fever and vomiting. Shortly after the onset the pal ient was comalose, the noek beeame stili, the pupils were dilated, reacting sluggishly to light, and the reflexes lecante incrested. Bxcept for two vesicles which were found on the clieekn, no eruption whs ohserved.

later there developed internal strubismus, tremor of the head and body, spusm of the hamstring muscles and cheyneStokes loreatliorg.

On several oechsions lumbar puncture was made; the fluid contaned, besides pmeumocoeci, many polynuclenr cells, lenko. cytes and red blool-eclls. 'lle tempernture ranged from 08.2 to do5, rising finally to $] 07.2$ loefore doath.

A uropssy.-Cerelorospinal moningritis was diagnosed. None of

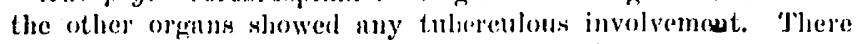
was marked dintention of the fourth ventricle.

Microscopic Examination.-The pin was flbrous and sparsely dotted with cells, mononuelear in type. The nuclei stuined poorly in the outer luyers of the thickened pia und in some the protoplasm was grumular while in others there were two nuclei present. In the inner layers there were many deceply staining, small and irregular nuclei. A few plasmatells were observed. Around the blood-vessels the cellular accumulation was marked, composed mainly of the connective-tissue type of ecll. There was also a slight proliferation of the intima of the small veins. In the cortex eapillary hemorrhnges were observed and there was some perivascular distention. In some of the cells four nuclei were olserved, suggesting karyokinesis.

This case was diagnosed as pneumococeus meningitis, the pnemmococeus having been found in the cerebrospinal fluid. It is of the mixed type showing proliferative and exuchative characteristics, and it is to be noted that microscopically it differed in no way from the usual picture of tubereulous meningitis.

\section{SUMMARY}

Of these cases only one (Case 4) properly belongs to the purely exulative type of tuberculous meningitis. l'hee (Nos. 2,5 and 7 ) are proliferative eases and three (Nos. 1, 3 and 6 ) are of the mixed type. Blood or blood pigment was found in eiglit (Nos. 1, 2, 3, 4, 5, 6, $f$ and 8 ) of the cases. Plasma cells were found in six of the cases ( Nos. 2, 3, 4, (i, 7 and 9 ).

Blood-vessel changes to a more or less degree were present in all the cases. Cortical changes were present in all the cases, in three of which marked evidence of encephalitis was observed. 'The duration of the discase secms to have little il' any bearing on the character of the exurate. The duration of the disense in the exudative type was four days; in the prolilerative type three weeks, twenty-seven days, eighty-one days and one of short duration; in the mixed type seventy-four days; thirty days, twenty-two days and one of short duration.

In this study an effort was maile to investignte the histologic characteristics of the process at those places removed from the tubercles themselves. 'I'lue lesion in all cases was more or less similar, except in the one case showing a purcly exulative type and this was, beyond cloubt, one of typical tubereulous meningitis.

Cases 8 and 9 are cloubtlul cases of tubereulous meningitis but the histologic findings are identical to those found in the other cases.

'This brings up the question as to the nature of so-called tuberculous meningitis. I believe that it is possible, il not probable, that the meningeal exudate in these cases is due to a mixed infection and not alone, or at all, to the toxins of the tuberele bacillus.

The rapidity of the course of the disense in these cases, which from its inception till the death of the patient is often bit a very few dias, is unlike the slow chronic process characteristic of tuberculosis in other organs. Moleover, in cases of tubereulosis of the meninges of patients who suceumb to this disease in other organs, the histologic picture is not the usual one found in the tubereulous meningitis of children.

The process in tubereulous meningitis, I believe, does not necessarily originate solely f'rom the tubercle bacillus or its toxins. 'The alusence of the bacillus of Koch, which is not unusual, speaks against it. Morcover, tha histologit: pieture of the lesion remover from the tuberele is of a round cell infiltation which, 1 believe, cannot be said to be pathognomonic of a tuberculous process.

Non-specific or simple inflammatory reactions in tubereulous meningritis have been aldeacly described by Villaret and 'Tixier,' I'eron," IIayen," Chantemesse and others.

Diffuse lenkocytic infiltration without tuberenlous granulations and willout definite tubereles and giant cells las also been observed by Siredey and 'Tinel."

1. Villaret and 'Ilixien' : Compt. rend. Soc. de blol, 1005, p. 600.

2. Joron: Aveh. gén. do méd., 1898, j) 413.

3. Iluyen: In Josura and Sulomon (Note 1(i).

4. Chintemesse: In Josuc nud Sulomon (Note 16):

b. Sllodey und 'Tinel: Lancel, London, April, 1007, p. 1033. 
T'hat it may be a mixed infection is well jllustrated in the observations of Perrin," who found the diplococei in the cerebu'ospinal fluid; of Kneass, Hendrickson and Suiler, ${ }^{7}$ who isolated the Mirrococens telragenus in the spinal fluid, as well as the tubercle bacilli in the smears from the tubercles in the meninges; of Griffon and Abrami, in whose case the cerebrospinal fluid was invaled by the $B$. coli; of Marotte," who described a case of septicemia of tetragenous origin coincident with tubereulous meningitis; and of Poissean and 'Tixier, ${ }^{10}$ in whose case were found diplococei not taking the Gram stain.

In two cases in my series, moreover, the diplococens was found in the cerebrospinal fluid. In this connection, however, should be mentioned the contention of Sieard, ${ }^{1}$ that the exudate in the pia is not the result of polymierobie infection and that the bacillus of Koch and $j$ ts toxins are capable in themselves of creating these granulations.

'The experimental evidence is somewhat conflicting. Hektoen ${ }^{2}$ failed to produce typical meningitis by injecting tubereles into the carotids of rabhits, though miliary tubereles were olserved in the meninges.

On the other hand, Sicard produced experimentally a diffuse process consisting of a leukocytic infiltration and other lesions similar to the diffuse meningeal changes found in man. There is no evidence in these experiments to exclude, however, the existence of a mixed inf'ection.

At the same time the experiments of . Martin and Vandremer, ${ }^{13}$ and Peron, ${ }^{14}$ show, according to these observers, that the toxins of tubereulosis play an important rôle in the development of tubereulous meningitis.

\section{OEldUULAR CIIANGES}

The cellular changes have been studied by Diamond, ${ }^{16}$ Josué and Salomon, ${ }^{10}$ Poissenu and 'Jixier, ${ }^{10}$ Higgs $^{17}$ and Siredey and 'l'inel."

Diamond ${ }^{15}$ found that the plasma cells, lymphoid cells. and phagocytic cells formed the prineipal cell-content of the infiltration of vascular leptomeningitis. He claims to have been the first to have described the presence of the plasma cell in acute tuberculous inflammation. The phagocytes were looked on as transmitting the tubercles from one area to another.

Iymphosytes and polynuclear cells predominated in the cases of tubereulous meningitis in adults studied by Josué and Salomon. ${ }^{10}$

In the case cited by Poissenu and Tixier.10 the cellular infiltation was composed of mononuclenr lymphocytes and endothelial cells without giant cells und finally, in the case of Siretey and 'J'inel, the exmmination slowed a diffuse leukocytic infiltration without tuberculous granulations or giant cells.

'The exulate in Higgs' case consisted of fibrin and round cells, mainly large and small lymplocytes, but some polymorphonuclear leukocytes.

f. Jeyln: IRev. med, de l'est., 1902, No. 34. 1. 1377.

$\tau$. Innegss, IIendrickson and Saller: Jour. Nerv. and Ment. Iris. 1003, p. 431 .

8. Cirifion and Abtamt: IBull, et mem. Soc. mod. d. hop. do liarls, 1006, xx111, 813 .

9. Marote: 13ull, med., 1009, p. 250.

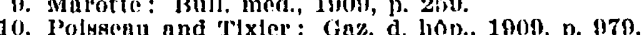

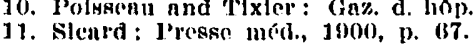

12. Ilektoen: Tr. Chlikeago l'ath. Soc., 1804-5, 1, 6!)

13. Murtln and Vandremer: Compt. rend. Soe. de blol., 1808, p 273.

14. I'eron: Arch. gén. de mécl., 1898, 11, 412.

15. Ilumond: Am. Jour. Med. Se. Now Sories, 1003, exxvl, 147

10. Josuc and sulomon: Bull. et mém. Soc. méd. d. hộ. de linis, 1903, xx, $11 \mathrm{di}$.

17. Hlggs: Brit. Mled. Jour., 1009, p. 1170.
The collular changes of the exuciate of tuberculous meningitis are not absolutely characteristic, somewhat similar changes having been described by Spielmever., ${ }^{18}$ as existing in trypanosomiasis and paresis (Geliry". though Gehry concludes that the miliary foei in the pia give the process a typienl appearance. While this is true, I think it still may be contended that the cellular makeup of the process remote from the tuberele is not typical of a tuberculous process.

\section{VASCULAR CILANGLS}

The blood-vessels exhibited, in ny cases, more or less change in seven of the nine cases studied. These changes consisted of thickening of the walls of the arterioles and some veins, which in one case went on to obliteration of the lumen of the small vessels. Perivascular round-cell infiltration was observed quite commonly. In some instances the conts of the veins were thickened and in others there was cellular proliferation of the intima. In one case an accumulation of round cells beneath the intima was observed; in another case cellular prolilerntion of the outer cont was demonstrated; and finally, in still another case the walls of the capillaries, in which the outer coat showed cellular proliferation, had undergone hyaline degeneration.

'The vaseular' ehanges described by Hektoen' ${ }^{12}$ which were present in all of his nine cases, consisting of a primary cularteritis and a phlehitis causing thrombosis and obliteration, were not uniformily present in my cases.

Hektoen believes that this primary endarteritis is due to the implantation of the tuberele bacilli on the intima. He describes, (1) a difluse form in which proliferation of the epithelioid rells occurs between the elastic lamina and the endothelium; (2) isolated miliary tubercle on the intima either singly or in conjunction with diffuse endarteritis, and (3) diffuse changes which proceed from periarterial foci.

The quotes the works of ITuguenin, Huttenbrener, Cornil and Hirschberg, who observed tubereulous endarteritis which was looked on as primary and due to the implantation of the tubercle on the intima.

Rindlleisch, '/ieglel, Birch-Hirschfeld, Iancerenu, Baumgarten, and Guernievi and others believed that the bacilli were localized in the adventitia, and Guernieri und Baumgarten described an endarteritis which they regarded as secondary (Hektoen ${ }^{12}$ ).

Blood-vessel changes have been described by Raymond, ${ }^{20}$ who found in the majority of the vessels of the pia an infiltantion of the sheatlis. Vascular changes have also been described by 1)iamond ${ }^{s}$ and LartutJacob and Sabareanu. ${ }^{21}$ In Dreher's case ${ }^{22}$ proliferation of the intima went on to obliteration of the lumen, and there was also perivascular infiltration.

Ettinger,":3 on the contrary, said that the absence of obliterating arteritis was striking and that the walls, and especially the external and middle cont, are a little thickened but uniformly so, and that the infiltration of the round cells is regular.

\section{ENCEPILALITIS}

A slight diffuse encephalitis is always present in these cases, according to Oppenheim. ${ }^{24}$

18. Spholmeyer: Die Trypanosomenkrankheiten, 1908.

10. Fohry: Areh. f. I'sychint., 1000, p. 69 .

20. Raymond : Rov. de Med., 1886, p. 2830

21. Iartat-Jucols and Subureunu: 13uill, et mem. Soc. anat. do Patis, 1004, p. 101.

22. Drohor: Dettsch. Ztschr. t. Nervenh., 1809, p. 68

23. Ittluger : Compt rend soc de blol. 189t, is 23.

24. Oppeabelm: Lelibuch der Nervenlellkunde, 1905, p. 77 . 
Distention of the perivascular spaces was noted in seven of the cases under discussion. In three cases there was marked round eell infiltration of the superficial layer of the cortex and in another capillary hemorrlyage was found. 'The cortex was rarified in two enses and the cerebellum was the seat of a marked encephalitis in one case.

In this connection the work of Jhermitte ${ }^{25}$ is interesting. He described tuberculous meningo-encephalitis and believed it impossible to deride, in a grent many cases based on the histologic findlings, whether the condition was ane of tuberctulous encephalitis or a simple (banale) inflammatory reaction. He found in these cases that the plasma cell was present in the cortex.

\section{PJASMAA CEIL,}

Studies of the plasma cell in tuberculous meningitis have not been made to any extent until within the last ten years. Wolf believed that they were regularly present in tuberculous meningitis and believed, furthermore, that degenerated plasma cells were found in all cases, though in varying amount, and raised the question whether these did not have some connection with regressive metumorphosis. Gehry" believed that the plasma cell playeel an important rôle in the regressive changes in the nerve-elements.

The rôle of the plasma cell in vascular tuberculous meningitis was described at length by I)iamond, ${ }^{15}$ who found them present in chronic and acute cases of tuberculous meningitis.

'Jlsey were not found in all of the cases reported in this paper. In six cases, however, they were present to a greater or less extent.

$\Lambda$ s to the origin or significance of the plasma cell, this paper docs not strictly pertain. Sulfice to suy that much has been written on the subject and whether the plasma cell originates from the lymphocyte, as Krompecher, ir Marschalko, ${ }^{23}$ Justi," Jo Joannovics,"30 Porcile," Comecitman,":" Herbert,"33 Jadassohn' ${ }^{34}$ and Schottlander"35 claim, or from the endothelial cell, as is believed by Unna, Elırlieh ${ }^{37}$ and others, is still a matter of dispute.

1732 P'ine strect.

\section{CHANGED PERSONALITY DUE TO HEAD INJURY}

\section{Q. STURGIS, M.D.} BEA'TTIL, W

Cases of lost personality are by no means rare, but they are always intensely interesting. As a rule, the personality is lost for a single period of time, either long or short. In the ease I wish to report, this mental lapse seems to lave persisted for about fourteen years, and since it lias received considerable publicity, a ful! rejort of the medical aspect cannot fail to be of value.

S. C. R. was brought to me late in the evening of oct. 13 , 1011, with the following incomplete history: Jo land been working in the suw-mill at Port Blakely, one of the near-by

25. Jherantte : IRov, Nemrol, 1910, p. 49).

27. Krompechel : Holtr. ". path. Anit, u. z. allg. Puth. (Zelgler's), $181) 8, \times x 1 v, 104$.

2x. Mal'sehalioo: Contralbl. 1'. allg. L'ath., 1890, p. 851.

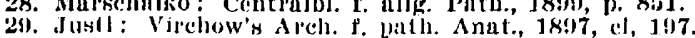

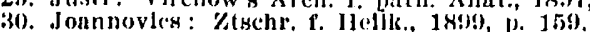

31. Porcle: IBoltr. z. [path. Annt. u. z. allg. Inth. (Zlegler's), 191)4, 1), 270 .

325. Councilman : Jour. loxper. Med., 180)8, p. 3983.

33. Horbelt : Joul. I'ath. and bacterlol., 1001, vil.

34. Indassohn: In Krompecher (Note 27).

35. Scholthunder: Ueber Hinrslocks 'Tubereul, 1897, 1). 81

36. Unna: In Krompecher (Note 27).

ij7. Whildil: Vlrehow's Arch. P. puth. Annt, 1904, clxxv, 198. towns, for a period of six months. Nine weeks before his entry to the hospital be loud been married. Nothing was known of lis previous history, but it was supposed that he had served a number of years in the navy. As far as anyone knew he had been a perfectly normal man. His habits han been exemplary. Thesday, October 11, while at work, le complaned of not fecling well; left work and returned to his home ubout 10 a. m1.; changed his clothes; nte his mid-day meal; and asked his wife what he might order for her from the store. He went to the store, left his order and was not seen again until about 9 p. m. Thursday, when a person living near the ontskirts of the village, attracted by the umusual actions of a collie dog, took a lantern and followed the dog into the brush to investignte. The patient was discovered nuked, moving aromed on lis lands and toes. Assistanee whs called; he was seized, handenfled and taken to the hospital, where he smaped at the attendants and gnawed at his chains until his teeth erumbled and broke. The next morning lie was taken before an insunity commission, which decided that he was not insune and sent him to seattle for trentment.

I. kaw him first at $10 \mathrm{p}$. m. liriday. He was in good physical condition; his body showed many scratches, especinlly over the knees and lege; he did not artienlate, but pointed to his ear and then to lis mouth, apparently sugresting that lo could hear but not speak. P'ujpils were equal and dilated; they did not renet. Head, neck, chest and ablomen were negative. Cremnsterie and knee-reflexes were much exucrerated, but equnl; on stroking the foot the toes flexed shapply and as sharply extended and spread widely. The pulse wris full and slow, with tension much increased-a typical pulso of incrensed intracrunial pressure; temperature and respiration were normal.

A tentative diagnosis of probubles uremia being made, suitable treatment wias institutel, even though a eatheterized specimen of mine sliowed no albumin.

The next morning his condition was considerably improved; the pulae-rate was between 70 and 80 , and the tension but slightly above normal. He was Hble to enturciate " word which sounded like "clothes," pointing the while to his naked body. I saw him again in the late afternoon. There had been a return of his cerebral symptoms. His pulse had dropped to 50 and was of very high tension. I noted for the first time that loe wiss probubly urable to see, sinee his eyes never foctsed on any point.

Tlie next morning, his conclition being unchanged, Dr. Georere Swift was asked to make a fundus examination, which he did shortly after noon. He reported a progressing elsoked disk in both eyes, but more marked in the right. At this time a white-cell comb slowed J(1,000, and the differentinl count 40 per cent. small monontelears, with a corresponding decrease in the polynuclen's. An immediate decompression wats decided on.

Under ether an osteoplustic flap, 31/2 inches square, was removed. The dur'a, which bulged tensely, was opened, disclosing a typical "wet brain," which oozed fluid so rapidly that it trickled in a fine stresm from the dependent portion of the wound. The dura was only partly closed, and the scalp wound was closed with druinate. The patient was removed to his room in grod conslition.

The morning of October If the pulse was still somewhat slow; the temperiture was normal; and the patient seened guite normal, except that there way some hernia of the brain. Ile complained much of liendache and was deciledly aphasic, asking with much diflieulty-apparently being unable to find the correct words-some few questions regarding himalf. When his wife enme in to see him he disl not recognize her and denied that he was matried.

Ile slept much of the dny and when I saw him the following morning he was much improved, there being but a slight aplusia and a lessened hernia of the brain. He evinced much interest in the dressing of his wound, and related to me that a wonan calling herself his wife had been in to see him. Ho stid: "Maybe she is, if she says she is, but I lanve never seen her before this." J). Robert l'erey Smitl, who examined him at this time, reported that "Kelly," ns we then enlled him, was in a condition of "mental confusion." When the patient was questioned he said that his name was not fielly, but that he could not remember his right name. 'That evening, for the first time, he said that his name was S. C. R., and that he lived with his "grunny." anul sister.

The day following-the loth-he objected to being called Kelly, and denied being muried. That afternoon be stated that he must have been unconscious when he was brought to the hospital, aa he recollected nothing beyond the evening before, and that he thought he had been in there about two 